\title{
Quantification of some secondary metabolites in selected Cornaceae species Stanovenie vybraných sekundárnych metabolitov v niektorých druhoch čel'ade Cornaceae
}

Abstract Leaves of selected species of the Cornaceae family (Swida alba, Swida australis, Swida controversa, Swida coreana, Swida baileyi, Cornus kousa, Cornus mas) were investigated in this study. These shrubs or small trees with hard wood are cultivated in Slovakia (Tesárske Mlyňany Arboretum). Some species (C. mas and C. kousa) have edible fruits. Cornels find broad ethnopharmacological use, for example, in Traditional Chinese Medicine (TCM), where fruits of $C$. officinalis are used for the treatment of several disorders, such as organ hypersecretion or diabetes. They are also used as tonics and for astringent effects. Leaves and fruits of C. kousa have been reported to possess antioxidative, anti-inflammatory and antidiabetic properties. The aim of our study is to compare the content of selected secondary metabolites groups in the leaves of above-mentioned species. The plant material was collected in the Tesárske Mlyňany Arboretum, Slovakia, in September 2010. Modified spectrophotometric methods of the European Pharmacopoeia, $8^{\text {th }}$ edition (Ph. Eur. 8) were used for all assays. Results show that the total hydroxycinnamic derivatives (THD) content varied from 1.14 (S. alba) to $2.86 \%$ (S. coreana) when expressed as rosmarinic acid, and from 1.01 (S. alba) to $2.55 \%$ (S. coreana) when expressed as caffeic acid. The flavonoids content ranged from 0.21 (C. mas) to 1.37\% (S. coreana), total polyphenols content from 9.6 (C. kousa) to 7.27\% (S. coreana), and tannins content from 7.17 (C. kousa) to $4.04 \%$ (S. coreana). Leaves of Korean dogwood (S. coreana) were observed to show the highest content of THD expressed as rosmarinic acid (2.86\%) and caffeic acid (2.55\%), as well as of flavonoids (1.37\%). Kousa dogwood (C. kousa) contained the highest amounts of tannins (7.17\%) and total polyphenols (9.6\%) on the other hand.

Slovak Predmetom nášho záujmu boli listy vybraných druhov čelade Cornaceae (Swida alba, Swida australis, Swida controversa, Swida abstract coreana, Swida baileyi, Cornus kousa, Cornus mas). Sú pestované na Slovensku (Arborétum Tesárske Mlyňany) a sú to kry alebo menšie stromy vyznačujúce sa tvrdým drevom. Niektoré druhy (C. mas a C. kousa) majú jedlé plody. Etnofarmakologické využitie drieňov a svíbov je široké, napr. Tradičná čínska medicína (TCM) používa plody C. officinalis na liečbu orgánovej hypersekrécie alebo diabetu. Využívajú sa aj pre svoje tonizačné a adstringentné účinky. Listy a plody C. kousa sú dôležité najmä pre svoju antioxidačnú, protizápalovú a antidiabetickú aktivitu. Ciel’om našej štúdie bolo porovnat' obsah vybraných skupín sekundárnych metabolitov v listoch uvedených druhov. Rastlinný materiál bol zbieraný v arboréte Tesárske Mlyňany na Slovensku v septembri 2010. Všetky stanovenia sa uskutočnili pomocou modifikovaných liekopisných metód podla Ph. Eur. 8. Výsledky ukazujú, že vo všeobecnosti obsah THD (celkové hydroxyškoricové deriváty) kolísal od 1,14 \% (S. alba) do 2,86 \% (S. coreana) pre kyselinu rozmarínovú a $1,01 \%$ (S. alba) do 2,55 \% (S. coreana) pre kyselinu kávovú. Obsah flavonoidov bol v rozmedzí od 0,21 \% (C. mas) do 1,37\% (S. coreana), obsah celkových polyfenolov od 9,6\% (C. kousa) do 7,27 \% (S. coreana) a trieslovín od 7,17\% (C. kousa) do $4,04 \%$ (S. coreana). Najvyššie množstvo THD vyjadrených ako kyselina rozmarínová (2,86 \%) a kyselina kávová (2,55 \%), ako aj flavonoidov (1,37 \%) obsahujú listy S. coreana. C. kousa na druhej strane obsahuje najväčšie množtvo trieslovín $(7,17 \%)$ a celkových polyfenolov $(9,6 \%)$.

Keywords Cornus-leaves-hydroxycinnamic derivatives-flavonoids-total polyphenols-tannins

Klúčové Cornus - listy-hydroxyškoricové deriváty - flavonoidy - celkové polyfenoly - triesloviny

slová:

\section{INTRODUCTION}

Cornaceae family species are shrubs or trees with very hard wood that have been used for manufacturing of various products, for example, musical instruments, bows, etc. In the area of central Europe, people still use fruits of Cornelian cherry (C. mas) for preparation of juices, syrups, and even an alcoholic distillate, drienkovica. Cornelian cherry fruits possess a pleasant taste (Forman, 2013).

*E-mail:forman@fpharm.uniba.sk

( ) Acta Facultatis Pharmaceuticae Universitatis Comenianae 
Cornels or their particular parts, find use in traditional medicines as well. They exhibit a broad spectrum of biological effects due to the presence of various active metabolites. The most important groups of secondary metabolites present in cornels are iridoids (Jeong et al., 2012), tannins (Hatano et al., 1989, 1989), triterpenes (Kim et al., 2011), flavonoids (Lee et al., 2000), lignans (Lee et al., 2007).

Many biological activities of cornels were described in literature. The root bark of $C$. florida was used as an antimalarial during World War II when the US depleted their quinine reserves. Current research confirms some antileishmanial activity as well (Graziose et al., 2012). Morroniside is an iridoid isolated from $C$. officinalis fruits that plays an important role as a neuroprotective agent (Wang et al., 2010). C. officinalis is also a part of various Traditional Chinese Medicine formulations for the treatment of kidney diseases, including diabetic nephropathy (Ma et al., 2014). Some other species have been tested for antidiabetic properties, for example, leaves and fruits of C. mas and C. kousa. Infusions of leaves of Cornus mas are traditionally used in the treatment of hyperglycaemia and consumed as herbal tea in Turkey. Leaves and fruits of $C$. kousa find very similar use as edible materials, and have been medicinally used for the treatment of diarrhoea, haemorrhaging and hyperglycaemia in eastern Asian traditional medicine. C. kousa leaves have been reported to contain various active compounds (isoquercitrin, tannin, gallic acid, chlorogenic acid), and their anti-hyperglycaemic effect is often attributed to the presence of chlorogenic acid as a potent hypoglycaemic agent. Some phenolic compounds are known to exert strong antioxidant activity, and C. kousa leaves were tested for their anti-inflammatory properties as well, positive results particularly obtained with water extracts (Celep, 2013, Daeyoung, 2011, Dinesh, 2009).

This study is based on the knowledge of interesting pharmacological activities and traditional uses of cornel leaves. The main goal of this preliminary study is to compare the content of selected groups of secondary metabolites in species cultivated in Slovakia.

\section{MATERIAL AND METHODS}

\section{Plant Material}

Leaves of selected cornel species were collected in September 2010 in the Tesárske Mlyňany Arboretum, Slovakia. Voucher specimens have been deposited at the Department of Pharmacognosy and Botany in herbarium (Comenius University in Bratislava, Slovakia).

\section{Chemicals}

Chemicals used for the extraction and for spectrophotometric assays were of p. a. purity: acetone, ammonium persulfate (10\% solution), anhydrous sodium sulphate, concentrated acetic acid, ethanol ( $50 \% \mathrm{v} / \mathrm{v})$, ethyl acetate, hydrochloric acid
(35\%, and $0.5 \mathrm{~mol} / \mathrm{l})$, methenamine, potassium hydroxide (2\%), sodium hydroxide (8.5\%) (Centralchem, Slovakia); aluminium (III) chloride, Arnow's reagent, phosphomolybdotungstic reagent, sodium carbonate (29\%), (Lachema, Czech Republic), caffeic acid (Merck, Germany), purified water.

\section{Equipment}

Analytical balance (JL-200, CHYO, Japan), Spectrophotometer (GenesysTM 6, Thermo Electron Corporation, UK)

\section{Methods}

Full methods as well as chemicals used are described in particular Ph. Eur. 8 monographs. Each method was modified slightly, for example, to fit the constant sample mass used, which was $0.600 \mathrm{~g}$. Methods are described in the respective monographs, as follows: a) spectrophotometric assay of total polyphenols and tannins (expressed as pyrogallol) (Ph. Eur. 8, 2013, Tannins in herbal drugs); b) spectrophotometric assay of flavonoids (expressed as hyperoside) (Ph. Eur. 8, 2013, Betulae folium); c) spectrophotometric assay of hydroxycinnamic derivatives expressed as rosmarinic acid (Ph. Eur. 8, 2013, Rosmarini folium), and expressed as caffeic acid using a calibration curve.

\section{RESULTS AND DISCUSSION}

The aim of this study is to compare the content of selected secondary metabolites groups in selected Cornaceae species cultivated in Slovakia.

Data shown in graphs (Figs. 1, 2 and 3) are the comparison of secondary metabolites content in the respective species. The results are expressed as average percentage values of three parallel measurements. Total hydroxycinnamic derivatives (THD) content is expressed as rosmarinic acid (Ph. Eur. 8), and as caffeic acid. The presence of this group of active compounds was reported in evaluated species before. As shown, S. coreana reaches the highest values ( $2.86 \%$ rosmarinic acid, and $2.55 \%$ caffeic acid, respectively), almost twice the value of other species. On the other hand, S. alba shows the lowest content of these substances $(1.14 \%$ rosmarinic acid, and $1.01 \%$ caffeic acid, respectively). Leaves of $S$. coreana show also the highest content of flavonoids $(1.37 \%)$, which is 3 to 4 times the value of other species. $C$. mas is the species with the lowest flavonoid content $(0.21 \%)$. The highest amount of total polyphenols and tannins was found in C. kousa (9.6\% total polyphenols, and $7.17 \%$ tannins, respectively) and the lowest percentage of these substances in S. coreana (7.27\% total polyphenols, and $4.04 \%$ tannins, respectively).

It can be noted as a general interesting observation that the species containing the highest amounts of flavonoids and hydroxycinnamic derivatives is also the one with the lowest content of total polyphenols and tannins. 


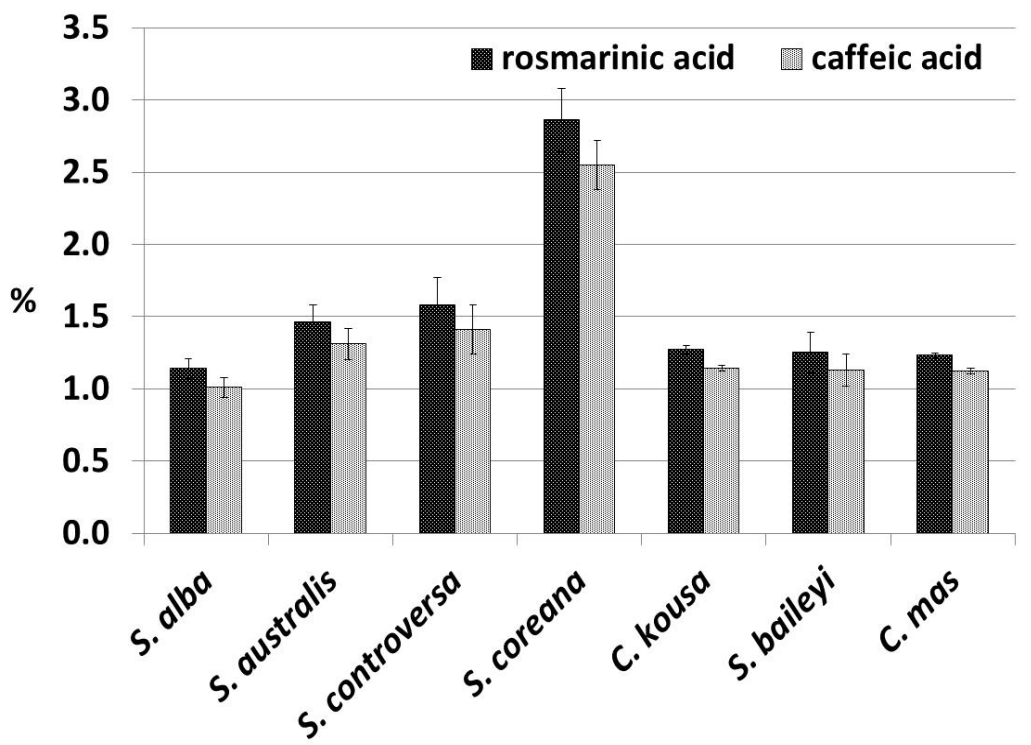

Figure 1. Hydroxycinnamic derivatives content in selected Swida (S.) and Cornus (C.) species, expressed as rosmarinic and caffeic acids [\%], $(n=3)$

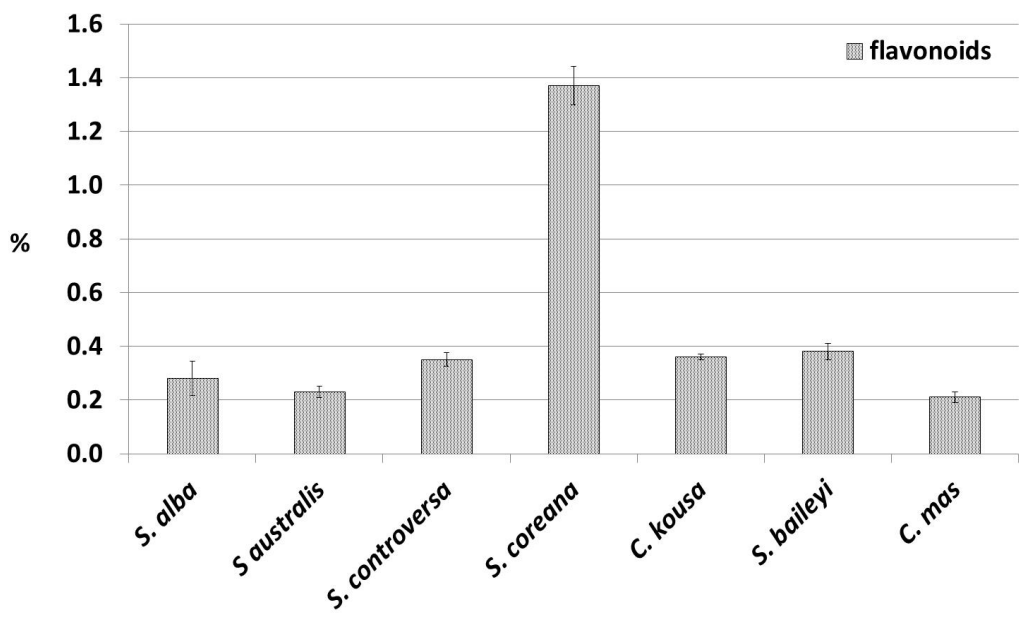

Figure 2. Flavonoids content in selected Swida (S.) and Cornus (C.) species, expressed as hyperoside [\%], $(n=3)$

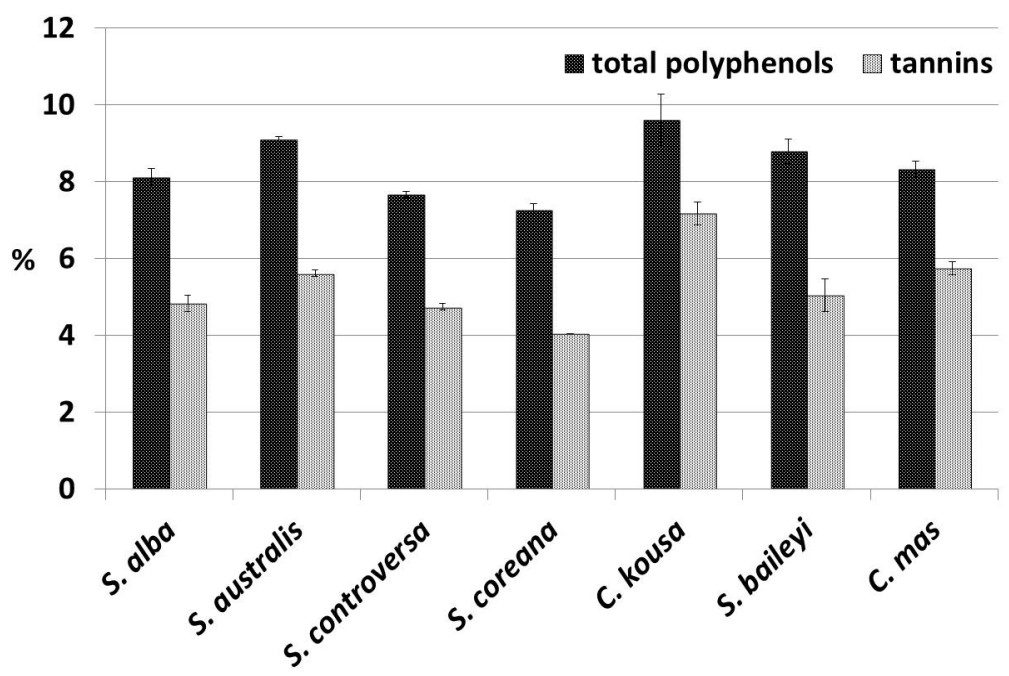

Figure 3. Total polyphenols and tannins content in selected Swida (S.) and Cornus (C.) species, expressed as pyrogallol [\%], ( $n=3$ ) 


\section{CONCLUSION}

The results of our quantification assays show that the THD content in the respective Swida and Cornus species varied from 1.14 (S. alba) to $2.86 \%$ (S. coreana) for rosmarinic acid, and from 1.01 (S. alba) to $2.55 \%$ (S. coreana) for caffeic acid. Flavonoids content was in the range from 0.21 (C. mas) to $1.37 \%$ (S. coreana), total polyphenols content from 9.6 (C. kousa) to $7.27 \%$ (S. coreana), and tannins content from 7.17 (C. kousa) to $4.04 \%$ (S. coreana), respectively. The highest amount of THD expressed as rosmarinic acid (2.86\%), and caffeic acid (2.55\%), as well as of flavonoids (1.37\%) was quantified in the leaves of Korean dogwood (S. coreana). Kousa dogwood (C. kousa) contained the highest amount of tannins (7.17\%) and total polyphenols (9.6\%), on the other hand.

\section{ACKNOWLEDGEMENT}

This study was supported by a grant of the Ministry of Education, Science, Research and Sport of the Slovak Republic, No.VEGA 1/0059/11, entitled Biological activities screening of selected medicinal plant species and identification of their active substituents.
[1] Celep E, Aydin A, Kirmizibekmez H, Yesilada E. Appraisal of in vitro and in vivo antioxidant activity potential of cornelian cherry leaves. Food Chem Toxicol. 2013;62:448-455.

[2] Daeyoung K, Kwang-Kyun P, Sang Kook L, Seung-Eun L, Jae-Kwan H. Cornus kousa F. Buerger ex Miquel increases glucose uptake through activation of peroxisome proliferator-activated receptor and insulin sensitization. J Ethnopharmacol. 2011;133:803-809.

[3] Dinesh B, Dinesh T, Jong Suk L. et al. Inhibitory effects of an aqueous extract of Cornus kousa Burg. leaves on TNF-a-induced chemokine expression and monocyte adhesion to human colonic epithelial cells. Arch Pharm Res. 2009;32:91-98.

[4] European Pharmacopoeia. $8^{\text {th }}$ edition. 2014;1369-1370 (01/2013:1560, Rosmarini folium);1173-1175 (04/2013:1174, Betulae folium);275-276 (01/2008:20814, 2.8.14. Tannins in Herbal Drugs).

[5] Forman V. Cornels (Cornus) and Dogwoods (Swida) - ornamental woods in parks and gardens, or more? (II). Liečivé rastliny. 2013;5:162-163 (in Slovak).

[6] Graziose R, Rojas-Silva P, Rathinasabapathy T. Antiparasitic compounds from Cornus florida L. with activities against Plasmodium falciparum and Leishmania tarentolae. J Ethnopharmacol. 2012;142:456-461.

[7] Hatano T, Yasuhara T, Okuda T. Tannins of cornaceous plants 2. Cornusiin-D, cornusiin-E and cornusiin- $F$, new dimeric and trimeric hydrolyzable tannins from Cornus officinalis. Chem Pharm Bull. 1989;37: 2665-2669.
[8] Hatano T, Ogawa N, Kira R, Yasuhara T, Okuda T. Tannins of cornaceous plants 1 . Cornusiin-A, cornusiin-B and cornusiin- $C$, dimeric, monomeric and trimeric hydrolyzable tannins from Cornus officinalis and orientation of valoneoyl group in related tannins. Chem Pharm Bull.1989;37:2083-2090.

[9] Jeong EJ, Kim TB, Yang H. et al. Neuroprotective iridoid glycosides from Cornus officinalis fruits against glutamate-induced toxicity in HT22 hippocampal cells. Phytomedicine. 2012;19:317-321.

[10] Kim KH, Choi SU, Kim YC, Lee KR. Tirucallane triterpenoids from Cornus walteri. J Nat Prod. 2011;74:54-59.

[11] Lee D, Kang SJ, Lee SH, Ro J, Lee K, Kinghorn AD. Phenolic compounds from the leaves of Cornus controversa. Phytochemistry. 2000;53:405-407.

[12] Lee DY, Song MC, Yoo KH. Lignans from the fruits of Cornus kousa Burg. and their cytotoxic effects on human cancer cell lines. Arch Pharm Res. 2007;30:402-407.

[13] Ma W, Wang KJ, Cheng CS. Bioactive compounds from Cornus officinalis fruits and their effects on diabetic nephropathy. J Ethnopharmacol. 2014;153:840-845.

[14] Wang W, Xu J, Li L. Neuroprotective effect of morroniside on focal cerebral ischemia in rats. Brain Res Bull. 2010;83:196-201. 